\title{
Heavy Metal Concentration of Surface Dust Present in E-Waste Components: The Westminister Electronic Market, Lagos Case Study
}

\author{
Adaramodu A. A. ${ }^{1}$, Osuntogun A. O. ${ }^{2}$, Ehi-Eromosele C. O., ${ }^{3, *}$ \\ ${ }^{1}$ Department of Chemistry, University of Lagos, Nigeria \\ ${ }^{2}$ Department of Chemistry, University of Lagos, Nigeria \\ ${ }^{3}$ Department of Chemistry, Covenant University, P.M.B. 1023 Ota, Nigeria
}

\begin{abstract}
To evaluate the extent of heavy metals $(\mathrm{Cd}, \mathrm{Cr}, \mathrm{Pb}, \mathrm{Zn}, \mathrm{Fe})$ contamination from e-waste, surface dust samples were collected from workshops (indoor), around the market areas (outdoor) and from a distance of about 100 metres away from the market area (control) of the Westminister Electronic market in Lagos, Nigeria. Aqua regia digestion was applied to the dust samples prior to determination of heavy metal by atomic absorption spectroscopy (AAS). The AAS analysis revealed mean concentrations in indoor dust $(\mathrm{Pb} 22.50$, Cd 1.80, Fe 108.00, $\mathrm{Cr} 0.35$ and $\mathrm{Zn} 295.50 \mathrm{mg} / \mathrm{kg})$, outdoor dust $(\mathrm{Pb}$ 15.90, Cd 19.00, Fe 103.3, Cr 0.10 and $\mathrm{Zn} 213.00 \mathrm{mg} / \mathrm{kg}$ ) and control dust ( $\mathrm{Pb} 9.40, \mathrm{Cd}-, \mathrm{Fe} 62.00, \mathrm{Cr}-$ and $\mathrm{Zn} 78.00$ $\mathrm{mg} / \mathrm{kg}$ ). Although the result showed a relatively low contamination in general, it could be inferred that the increased concentration of heavy metals from the indoor electronic waste could be from the interaction of heavy metals in the e-waste components with the settled dust on them over time. Risk assessment predicted that $\mathrm{Cd}$ and $\mathrm{Zn}$ in the e-waste have the potential to pose serious health risks to workers, customers and local residents of Westminister area, especially children, and this underscores the urgent intervention by relevant government agencies.
\end{abstract}

Keywords E-Waste, Heavy Metals, Surface Dust, Risk Assessment

\section{Introduction}

e-waste broadly covers waste from all electronic and electrical appliances and comprises of items such as computers, mobile phones, digital music recorders/players, refrigerators, washing machines, televisions (TVs) and many other household consumer items[1, 2]. E-waste products contain intricate blends of plastics and chemicals, which when not properly handled can be harmful to people and the environment[3]. The composition of e-waste is very diverse and differs in products across different categories. It contains more than 1000 different substances, which fall under 'hazardous' and 'non-hazardous' categories. The presence of elements like lead, mercury, arsenic, cadmium, selenium and hexavalent chromium and flame retardants beyond threshold quantities in e-waste classifies them as hazardous waste[4].

Electronic waste or e-waste is one of the rapidly growing problems of the world. It is estimated that 20-50 million tons of electric and electronic waste is generated per year of which $75-80 \%$ is shipped to countries in Asia and Africa for recycling and disposal. In these countries recycling of e-

* Corresponding author:

cyril_720@yahoo.com (Ehi-Eromosele C.O.)

Published online at http://journal.sapub.org/re

Copyright (C) 2012 Scientific \& Academic Publishing. All Rights Reserved waste is performed with limited and often no environmental or worker health precautions. Activities at these sites often pose harmful threats in the form of soil pollution leading to contaminated water and food as well as air contaminants affecting the health of the workers and children at these sites[5].

While over 80 per cent of the world's high-tech wastes lands up in land-fills in Asia and Africa, Nigeria is emerging as one of the top dumping grounds for toxic, chemical and electronic waste from the developed world[6]. According to the Basel Action Network (BAN), a Seattle-based environmental group, an estimated 500 shipping containers with a load equal in volume to 400,000 computer monitors or 175,000 large TV sets enter Lagos, Nigeria each month. As much as 75 percent of such shipments are classified as e-waste[7]. The recycling, parts salvaging, distribution and the disposal of these discarded electronic devices are now creating a new set of environmental and public health challenges in Nigeria.

Dust is a significant environmental media that can provide information about the level, distribution, and fate of contaminants present in the surface environment. As the composition of settled dust is similar to atmospheric suspended particulates, it can be an indicator of pollutants such as heavy metal contamination in the atmosphere[1,8]. The level of heavy metal concentration may be evaluated from the level 
of dust deposition per unit area and metal concentrations in the deposit[9]. Hence the level of heavy metal concentration in dust found within the lattices of electronic waste is evaluated in this study. This is because most e-wastes often contain dust particles embedded within their various components and as such poses health risks when dismantled and piled up in stores without proper disposal.

Humans can become exposed to heavy metals in dust through several routes which include ingestion, inhalation, and dermal absorption. In dusty environments, it has been estimated that adults could ingest up to $100 \mathrm{mg}$ dust/day. Children are usually exposed to greater amounts of dust than adults as a result of pica and play behavior[1,10,11]. Exposure to high levels of heavy metals can result in acute and chronic toxicity, such as damage to central and peripheral nervous systems, blood composition, lungs, kidneys, liver, and even death. Lead levels in dust have been significantly associated with $\mathrm{Pb}$ levels in children's blood[1,12], and a blood lead level (BLL) greater than an intervention level of $10 \mu \mathrm{g} \mathrm{Pb} / \mathrm{dL}$ has been associated with a decrease in IQ $[1,13]$.

Two recent studies have demonstrated elevated body loadings of heavy metals[14] and persistent toxic substances [15] in children and e-waste workers, respectively, at Guiyu, China. Although there is paucity of data on post impact e-waste environmental studies in the Africa region, a recent study in Nigeria has demonstrated high concentrations of copper, nickel, zinc and lead in soils far in excess of European Union limits at e-waste dump sites in Lagos, Benin, and Aba cities in Nigeria[16]. Contamination of plants and nearby surface waters in e-waste disposal sites by heavy metals was also reported in these sites[16]. Another study showed that the mean concentration $(\mathrm{mg} / \mathrm{kg})$ of $\mathrm{Cu}$ and $\mathrm{Pb}$ in Printed Circuit Boards (PCB) of CPU and monitor of computers were found to be over 50 folds higher than the Toxicity Threshold Limit Concentration (TTLC) for the metals in electrical and electronic equipment in developed countries [17]. The excessively high concentrations of $\mathrm{Cu}$ and $\mathrm{Pb}$ in the components of the computers analyzed suggest that these used computers are hazardous wastes. Consequently, improper disposal of the PCBs of the CPU and monitors in the environment may pose serious risk to humans and the environment[18].

The objectives of this study were to quantify the amount of heavy metal present in surface dust collected from outside casing and lattices of electronic wastes across workshops and environs in a popular electronic market in Nigeria (West Minister market) and to estimate the potential health risk to adults and children via dust ingestion.

\section{Materials and Methods}

\section{Study Area}

Westminster Electronic Market is situated in Apapa Local Government Area of Lagos, Nigeria, close to the Lagos Tincan Island Port. Its location has made it an attractive point for disembarking and selling Used Electrical and Electronic Equipment (UEEE). The market has about 300 outlets where all types of UEEE are sold. Additionally, the market also has large storing facilities, which make it a big hub for storing UEEE before being redistributed to other markets or exported to neighbouring countries[19].

\section{Sample collection and preparation}

Three categories of dust samples were randomly collected between November 2009 and January 2010 during the dry season, when the prevalence of dust was expected to be high.

Dust samples were collected from the surfaces of printed circuit boards, plastic casings, cathode ray tubes and other internal and external components of e-waste across different stores within the market by careful brushing with plastic brushes into plastic containers. This was tagged indoor dust.

Surface dust was also collected randomly from bare ground across the market area outside the workshops. This was tagged Outdoor dust

Surface dust was also collected from a place 100 meters away from the market area where heavy metal contribution from e-waste is not present. The samples were homogenized and mixed. This was used as control.

Each representative sample was stored in polyethylene bags which had been previously treated overnight with dilute $\mathrm{HNO}_{3}$. They were then placed in dessicators to get rid of moisture and ground into fine powder. Dry samples were sieved with $0.125 \mathrm{~mm}$ sieve and homogenized. This particle size range was chosen to facilitate comparison of heavy metal concentration with soil guidelines.

\section{Sample Digestion and Analysis}

$1 \mathrm{~g}$ of a well homogenized sample obtained from sample preparation procedure above was approximately weighed to the nearest $0.0001 \mathrm{~g}$ into a Kjeldahl flask and $12 \mathrm{ml}$ of freshly prepared aqua regia $\left(3 \mathrm{ml} \mathrm{HNO}_{3}+9 \mathrm{ml} \mathrm{HCl}\right.$ i.e. ratio 1:3) was added. The beaker was covered and the contents heated for 2 hours on the medium heat of a hot plate until all bubbling had ceased. The mixture was allowed to cool and then filtered through a Whatman No. 42 filter paper into a $50 \mathrm{ml}$ standard volumetric flask. The filtrate was diluted to $50 \mathrm{ml}$ with de-ionized distilled water. Blank solutions were also prepared. The concentrations of lead, cadmium, iron, chromium and zinc in the solution were measured by Perkin Elmer 1100 atomic absorption spectrometer. All the samples were prepared and determined in duplicates and the data obtained were analysed using statistical tools. The digested samples were analysed in duplicates with the average concentration of the metal present being displayed in $\mathrm{mg} / \mathrm{L}$ by the instrument after extrapolation from the standard curve and it was converted to $\mathrm{mg} / \mathrm{Kg}$.

\section{Risk Assessment}

Risk assessment due to exposure to metal polluted in dust was carried out to estimate the cancer toxic (chronic) risk of workers exposed to the dust occupational hazards of traders and consumers exposed at the Westminister electronics 
market. Estimation of risk was calculated using USEPA exposure factors handbook[20]. Average daily dose (ADD) of dust ingested was determined using the equation below.

$$
\mathrm{ADD}=\underline{\mathrm{C} \times \operatorname{IngR} \times \mathrm{EF} \times \mathrm{ED}}
$$$$
\mathrm{Bw} \times \mathrm{AT}
$$

$\mathrm{C}=$ mean heavy metal Concentration

IngR $=$ dust ingestion rate $(100 \mathrm{mg} /$ day for adults and $200 \mathrm{mg} /$ day for children)

$\mathrm{EF}=$ exposure frequency of 260 working days/year

$\mathrm{ED}=6$ years for children and 24 years for adults

$\mathrm{Bw}=$ Body weight of $60 \mathrm{~kg}$ for adults and $15 \mathrm{~kg}$ for children was assumed

$\mathrm{AT}=$ Averaging time of 1300 days in 5 years.

\section{Results and Discussion}

$\mathrm{RD}=\mathrm{RIS}$ reference dose absorbed both oral and dermal (through the skin)

$\mathrm{ADD}=$ average daily dose of heavy metals ingested from dust

$\mathrm{HQ}=$ hazard quotient

Table 1 shows the concentrations of $\mathrm{Pb}, \mathrm{Cd}, \mathrm{Fe}, \mathrm{Cr}$ and $\mathrm{Zn}$ in $\mathrm{mg} / \mathrm{kg}$ in the various samples analysed. Figure 1(a) - (e) shows the metal concentrations in the indoor dust, outdoor dust and control dust samples. Table 2 shows the average daily dose of indoor dust ingested by adults and children and corresponding occupational hazard quotient. The mean heavy metal concentrations in indoor dusts were higher than the dust collected from the outdoor environment and control dust. Generally, concentrations of heavy metals in control dust were relatively lower than the indoor and outdoor samples. This difference showed that there were heavy metal pollution activities within the area. Currently, there are no guidelines or regulations for heavy metals in dust[3]. To evaluate the extent of heavy metal contamination in the dust, the concentrations were compared to the New Dutch List Guidelines and the European Union Limits for these heavy metals in soils. Compared with other studies carried out in similar environmental media, the result of this study showed a relatively low contamination in general. This might be due to the fact that it is mainly the sale of UEEE and not its recycling that is carried out in the shops sampled at the Westminister Electronic Market. Notwithstanding, since toxicity is associated with continuous low level exposure, these reported mean heavy metals concentration can eventually lead to serious health effects.

Table 1. Concentrations of heavy $\mathrm{Pb}, \mathrm{Cd}, \mathrm{Fe}, \mathrm{Cr}$ and $\mathrm{Zn}$ in $\mathrm{mg} / \mathrm{kg}$

\begin{tabular}{|c|c|c|c|}
\hline Heavy Metals & Indoor Dust & Outdoor Dust & Control Dust \\
\hline Lead $(\mathrm{mg} / \mathrm{Kg})$ & 22.5 & 15.90 & 9.40 \\
\hline Cadmium $(\mathrm{mg} / \mathrm{Kg})$ & 19.00 & 1.80 & $\mathrm{ND}$ \\
\hline Iron $(\mathrm{mg} / \mathrm{Kg})$ & 108.00 & 103.30 & 62.00 \\
\hline Chromium $(\mathrm{mg} / \mathrm{Kg})$ & 0.35 & 0.10 & $\mathrm{ND}^{*}$ \\
\hline Zinc $(\mathrm{mg} / \mathrm{Kg})$ & 295.50 & 213.00 & 78.00 \\
\hline
\end{tabular}

*Not Detected

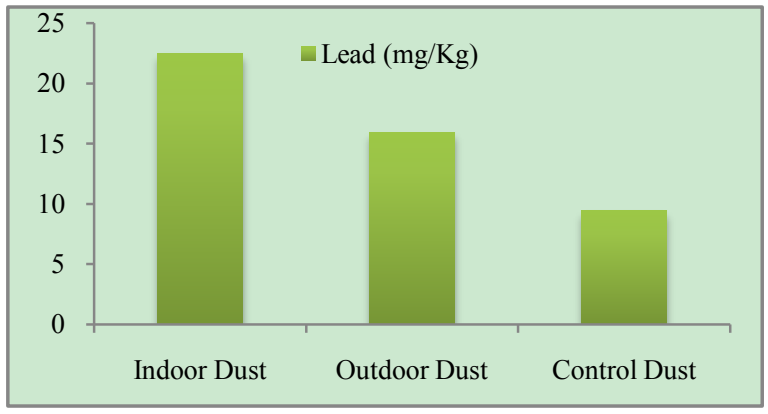

(a)

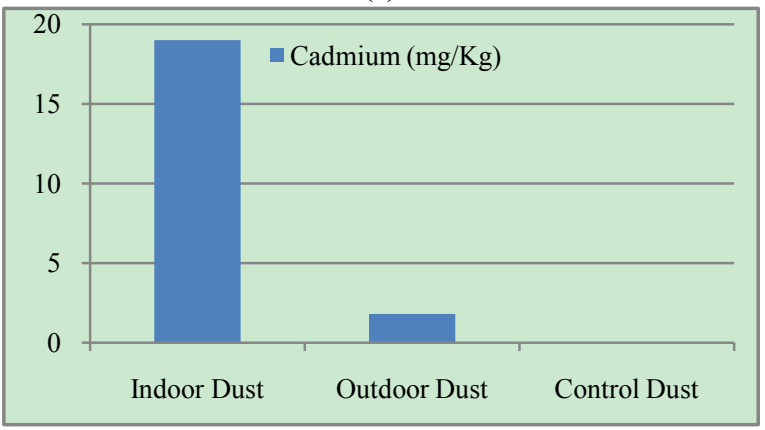

(b)

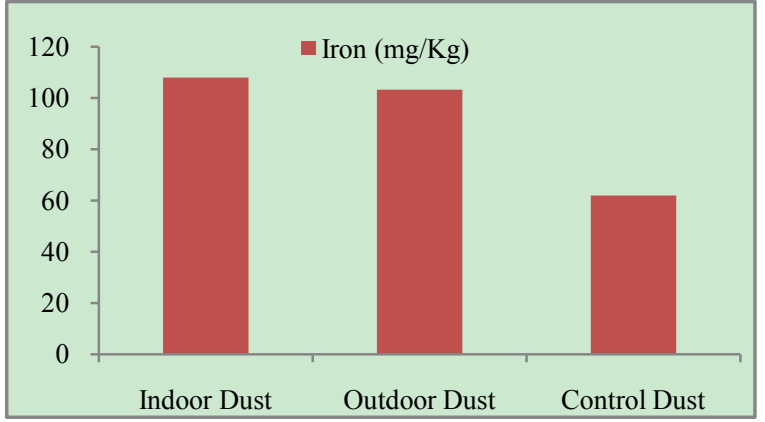

(c)

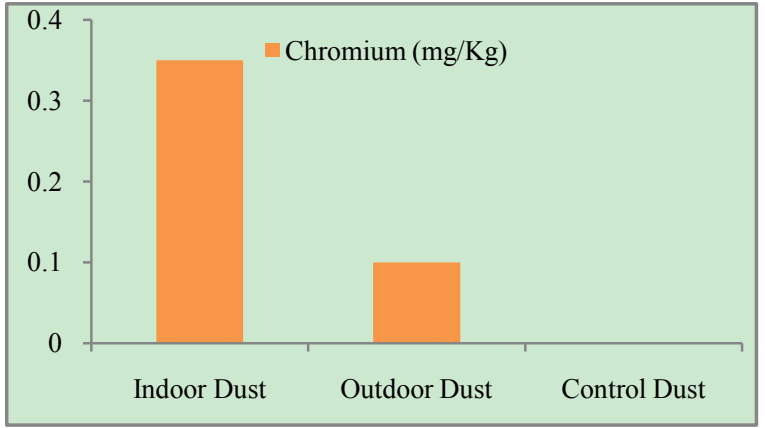

(d)

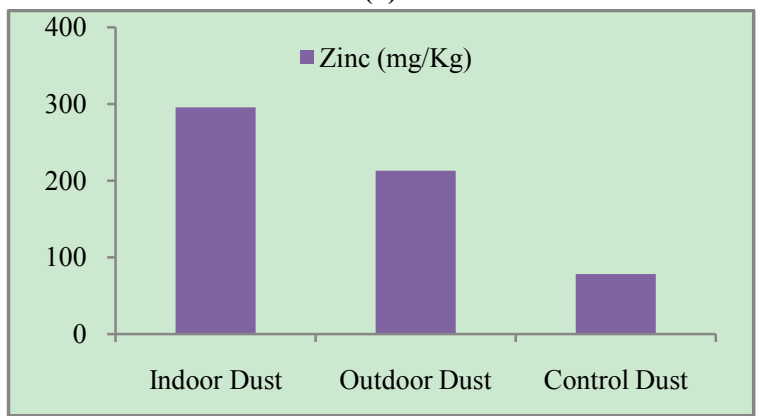

(e)

Figure. 1. (a) - (e) shows the metal concentrations in the indoor dust, outdoor dust and control dust samples 
Table 2: Average daily dose of indoor dust injested by adults and children and corresponding occupational hazard quotient

\begin{tabular}{|c|c|c|c|c|c|c|c|c|}
\hline Heavy metals & $\begin{array}{c}\text { RD (oral) } \\
\mathrm{mg} / \text { day }\end{array}$ & $\begin{array}{c}\text { RD (dermal) } \\
\mathrm{mg} / \text { day }\end{array}$ & $\begin{array}{c}\text { ADD adults } \\
\text { (mg/day) }\end{array}$ & $\begin{array}{c}\text { ADD } \\
\text { children } \\
\text { (mg/day) }\end{array}$ & $\begin{array}{c}\text { HQ adults } \\
\text { (oral) }\end{array}$ & $\begin{array}{c}\text { HQ chil- } \\
\text { dren } \\
\text { (oral) }\end{array}$ & $\begin{array}{c}\text { HQ adults } \\
(\text { dermal })\end{array}$ & $\begin{array}{c}\text { HQ chil- } \\
\text { dren } \\
(\mathrm{dermal})\end{array}$ \\
\hline Lead $(\mathrm{mg} / \mathrm{kg})$ & 0.3 &. & 0.0002 & 0.0004 & 0.0067 & 0.013 &. &. \\
\hline Cadmium $(\mathrm{mg} / \mathrm{kg})$ & 0.001 & 0.00001 & 0.000014 & 0.00028 & 0.014 & 0.0028 & 1.4 & 2.8 \\
\hline Chromium $(\mathrm{mg} / \mathrm{kg})$ & 0.003 & 000075 & 0.000003 & 0.000006 & 0.001 & 0.002 & 0.004 & 0.008 \\
\hline Zinc $(\mathrm{mg} / \mathrm{kg})$ & 0.002 & 0.054 & 0.0024 & 0.0048 & 1.2 & 0.0096 & 0.4 & 0.8 \\
\hline
\end{tabular}

The Lead concentration for the Indoor dust sample was $22.50 \mathrm{mg} / \mathrm{Kg}, 15.90 \mathrm{mg} / \mathrm{Kg}$ for the outdoor and $9.40 \mathrm{mg} / \mathrm{Kg}$ for the control dust samples. The higher concentration of Lead in the indoor could be assumed to be as a result of contribution of e-waste to the overall Lead concentration in indoor dust. This is to say that there is interaction between e-waste and dust deposited on them over time. Mean $\mathrm{Pb}$ concentration for the samples were all below the New Dutch List optimum value $(85 \mathrm{mg} / \mathrm{Kg})$ and EU limits (50$300 \mathrm{mg} / \mathrm{kg}$ ). $\mathrm{Pb}$ exerts toxic effects on various systems in the body such as the central (organic affective syndrome) and peripheral nervous systems (motor neuropathy), the hemopoietic system (anemia), the genitourinary system (capable of causing damage to all parts of the nephron) and the reproductive systems (male and female)[21]. The mean $\mathrm{Cd}$ concentrations of indoor dust $(19 \mathrm{mg} / \mathrm{kg})$ were also found to be higher than the outdoor dust $(1.8 \mathrm{mg} / \mathrm{kg})$ while none was detected in the control. The mean $\mathrm{Cd}$ concentrations in all the samples were found to be above the New Dutch List optimum value $(0.8 \mathrm{mg} / \mathrm{Kg})$ and also its action value $(12 \mathrm{mg} / \mathrm{kg})$ except for the outdoor dust. This is of concern because $\mathrm{Cd}$ is a potentially long-term cumulative poison. Toxic cadmium compounds accumulate in the human body, especially in the kidneys. There is evidence of the role of cadmium and beryllium in carcinogenicity[22].

The mean $\mathrm{Fe}$ concentration of indoor dust $(108 \mathrm{mg} / \mathrm{Kg})$ was found to be higher than the outdoor dust $(103.30 \mathrm{mg} / \mathrm{Kg})$ and control dust $(62 \mathrm{mg} / \mathrm{Kg})$. The comparatively high amounts of Fe can be traced to its high presence in electronics. For example a typical desktop computer contains about $20.4712 \%$ of iron by weight of the total desktop weight. Chronic inhalation of excessive concentrations of iron oxide fumes or dusts may result in development of a benign pneumoconiosis, called siderosis, which is observable as an $\mathrm{x}$-ray change[23].

The mean Cr concentration of indoor dust was $0.35 \mathrm{mg} / \mathrm{Kg}$, $0.10 \mathrm{mg} / \mathrm{Kg}$ for outdoor dust and none was detected in the control sample. The low concentrations of chromium in the samples might be due to its small amount in e-waste and also in nature. The health hazards associated with exposure to chromium are dependent on its oxidation state. It has been known to cause a lot of health problems like skin rashes, kidney and liver damage and also a possible carcinogen in humans[23]. The mean $\mathrm{Zn}$ concentration of indoor dust was $295.50 \mathrm{mg} / \mathrm{Kg}, 213.0 \mathrm{mg} / \mathrm{Kg}$ for outdoor dust and $78 \mathrm{mg} / \mathrm{Kg}$ in the control dust. $\mathrm{Zn}$ concentrations in the samples were the highest compared to the other metals. The mean $\mathrm{Zn}$ concen- tration in the indoor and outdoor dust samples were above the New Dutch List optimum value $(140.0 \mathrm{mg} / \mathrm{Kg})$ but were below its action value $(720.0 \mathrm{mg} / \mathrm{Kg})$. The control sample had $\mathrm{Zn}$ concentration below the New Dutch List optimum and action values yet again confirming the interaction between heavy metals in e-waste and dust deposited on them over time. Zinc is an essential element in our diet. Too little zinc can cause health problems, but too much zinc is also harmful. Breathing large amounts of zinc (as dust or fumes) can cause a specific short-term disease called metal fume fever.

\section{Risk Assessment}

The average daily dose of heavy metals ingested in dust per day in adults and children through the mouth (oral) and skin (dermal) route is calculated by using the RAIS oral and dermal chronic reference doses in $\mathrm{mg} /$ day and heavy metal concentrations shown in Table 1. It has been established that $\mathrm{HQ} \geq 1$ is an indication of risk of cancer hazard. Oral hazard quotient (HQ 1.2) for Zinc in adults indicates a risk of zinc toxicity as a result of large amount of zinc that could be ingested by adults. Dermal HQ results of 1.4 and 2.8 for Cadmium recorded in adults and children respectively indicates a high risk of cancer, lung damage, high blood pressure and kidney damage. Children run a greater risk of cadmium toxicity because of its higher hazard quotient.

\section{Conclusions}

The difference in the concentration of consecutive heavy metals in indoor and outdoor dust in this study supports the inference that: there is interaction between heavy metals within the components of e-waste and their surface dust, such as to contribute to the overall increase in metal concentration of the indoor dust. Hazard quotient results also indicates that electronic dealers who store e-wastes and consumers who patronize the electronics market run a risk of zinc toxicity in adults and cadmium toxicity if this continues consecutively for a period of 5 years ingestion of dust either orally or dermally. Also, Children run a greater risk of consuming more dust per day and as such contact illness due to heavy metal toxicity. 


\section{REFERENCES}

[1] Sinha, S., Downside of the Digital Revolution. Published in Toxics Link, 28/12/2007. Available from: http:// www.toxicslink.org/art-view.php?id=124

[2] Pinto, V.N., E-waste hazard: The impending challenge, Indian J Occup Environ Med. 2008 August; 12(2): 65-70

[3] Leung, A.O., Cai, Z.W., Wong, M.H., Environmental Contamination from Electronic Waste Recycling at Guiyu, southeast China. Journal of Material Cycles Waste Management 2006; 8(1):21-33.

[4] Available from: http:// www.cpcb.nic.in/ Electronic\% 20Waste/Chapter1-2.html.

[5] Caravanos, J., Clark, E., Fuller, R. and Lambertson, C., Assessing Worker and Environmental Chemical Exposure Risks at an e-Waste Recycling and Disposal Site in Accra, Ghana, Blacksmith Institute Journal of Health and Pollution, Vol. 1, No 1 (2011)

[6] http://www.greendiary.com/entry/e-waste-poisoning-in-niger ia/

[7] http://ipsnews.net/news.asp?idnews $=40893$

[8] Akhter, M. S. and Madany, I. M. Heavy metals in street and house dust in Bahrain, Water Air Soil Pollut. 199366 111-119.

[9] Krolak, E., Heavy metals in fallen dust in Eastern Maziwiekie province, Polish Journal of environmental studies, (2000) Vol. 9, No. 6, pp 517- 522.

[10] Murgueytio, A. M., Evans, R. G., Sterling, D. A., Serrano, F. and Roberts, D., Behaviours and blood lead levels of children in a lead-mining area and a comparison community, J. Environ. Health 1998601420

[11] Centers for Disease Control and Prevention. Preventing Lead Poisoning in Young Children; Centers for Disease Control: Atlanta, GA, 2005

[12] Lanphear, B. P. and Roghmann, K. J., Pathways of Lead Exposure in Urban Children, Environ. Res. 1997746773

[13] Centers for Disease Control and Prevention. Preventing Lead
Poisoning in Young Children; Centers for Disease Control: Atlanta, GA, 2005

[14] Huo, X., Peng, L., Xu, X. J., Zheng, L. K., Qiu, B., Qi, Z. L., Zhang, B., Han, D., and Piao, Z. X., Elevated blood lead levels of children in Guiyu, an electronic waste recycling town in China Environ. Health Perspect. 20071511131117

[15] Bi, X. H., Thomas, G. O.; Jones, K. C.; Qu, W. Y.; Sheng, G. Y.; Martin, F. L.; Fu, J. M. Exposure of electronics dismantling workers to polybrominatetd diphenyl ethers, polychlorinated biphenyls, and organochlorine pesticides in South China Environ. Sci. Technol. 20074156475653

[16] Nnorom, I. C., (2009): Heavy metal pollution at selected electronic waste disposal sites in parts of southern Nigeria. Draft Phd thesis, University of Ibadan, Chemistry Department, Nigeria.

[17] Olubanjo, K. A. (2009): Heavy metals in used computers in Nigeria; MSc Dissertation, University of Ibadan, Chemistry Department, Nigeria.

[18] Osibanjo, O. (2009) Electronic waste: A major challenge to sustainable development in Africa, Basel convention regional coordination centre for Africa, Ibadan, Nigeria. oosibanjo@yahoo.com

[19] Odeyingbo, O.O., (2011) Assessment of the flow and driving forces of used electrical and electronic equipment into and within Nigeria, M.Sc Thesis submitted to BTU, Cottbus, Germany.

[20] USEPA (1997) Exposure factors handbook, EPA/600/p-95/ $002 \mathrm{Fa}, \mathrm{b}, \mathrm{c}$ : environmental protection agency office of research and development, Washington DC.

[21] Harrington, J.M., Aw, T.C., Baker, E.L., Occupational and environmental health and safety. In: David AW, Timothy MC, John DF, Edward JB, editors. Oxford Textbook of Medicine. 4th ed. Vol. 1. New York: Oxford University Press; 2003. pp. 956-60. Chap.8.4.1.

[22] Pruss-Ustun, A., Corvalan, C., Preventing disease through healthy environments: Towards an estimate of environmental burden of disease. WHO Publication. 2006:45.

[23] http://www.lenntech.com/periodic/elements/cr.htm 